\title{
CARS 顕微鏡による混合気流の非侵襲濃度分布計測
}

\section{Non-intrusive Measurement of Concentration Distributions in Gas Mixture Flow by CARS Microscopy}

○守屋 まどか（慶大理工）山租 侑生（慶大院）栗山 怜子（慶大院）

山本 憲 (慶大理工) 正佐藤 洋平 (慶大理工)

Madoka Moriya, Yuki Yamagata, Reiko Kuriyama, Ken Yamamoto and Yohei Sato

Keio University, 3-14-1 Hiyoshi, Kohoku-ku, Yokohama 223-8522

\begin{abstract}
This study describes a non-intrusive measurement of the distribution of $\mathrm{CO}_{2}$ and $\mathrm{N}_{2}$ concentrations in gas mixture flow by coherent anti-Stokes Raman scattering (CARS) microscopy for the development of a non-intrusive measurement technique in microscale gas flow. The relationship between $\mathrm{CO}_{2} / \mathrm{N}_{2}$ ratio and CARS intensity generated from $\mathrm{CO}_{2}$ and $\mathrm{N}_{2}$ was acquired. Concentrations of both gases were measured at ten different points in the flow channel where $\mathrm{CO}_{2}$ and $\mathrm{N}_{2}$ were mixed. The maximum standard deviations of measurement data of $\mathrm{CO}_{2}$ and $\mathrm{N}_{2}$ concentrations were $3.90 \%$ and $5.58 \%$, respectively. It was shown that the measurement of the gas concentrations in a microscale region $\left(2.5 \times 2.5 \times 44.5 \mu \mathrm{m}^{3}\right)$ where CARS was generated was realized.
\end{abstract}

Key Words: Non-intrusive measurement, CARS, Gas mixture flow, Concentration

\section{1. 緒言}

近年, 微小流路内において試料の化学分析を行うマイク ロガス分析システムム(1)の開発が進められており，環境分析 や医療分野における利用が期待されている。 シスラム内芯 の化学反応の高効率化のためには流路内における気体の挙 動解明が不可欠である. レーザ誘起巣光(LIF)法を用いたマ イクロスケールの気液界面における気体溶解現象の解明 ${ }^{(2)}$ が過去に行われたが，気体流動現象を直接計測することは できなかった。また，LIF 法は流体一の学光色素混入によ る化学的影響が想念されるため, 非侵襲な気体の計測法が 求められている，本研究では，マイクロスケールにおおける 気体の非侵襲計測法の開発を月指し，エンジン等での気体 の濃度計測 ${ }^{(3)}$ に用いられてきた Coherent anti-Stokes Raman Scattering(CARS)を用いて $\mathrm{CO}_{2} \cdot \mathrm{N}_{2}$ 混合気流の濃度分布の 非侵襲計測を行う。

\section{2. 原理}

本研究では, CARS を用いて $\mathrm{CO}_{2} \cdot \mathrm{N}_{2}$ 混合気体の濃度計 測を行う. ボンブ光 $\left(v_{\text {pump }}\right) \cdot$ ストークス光 $\left(v_{\text {Stokes }}\right)$ と呼ばれ る振動数り異なるレーザ光を試料分子に照射し， 2 本の入 射光の振動数差が分子の振動数に一致すると，分子の振動 運動が励起され，式(1)を満たす振動数の CARS 光( $v_{\text {CARS }}$ ) が発生する．また，分子振動数を光速で除したものをラマ ンシフトといい，分子に圆有な值をとる.

$$
v_{\text {CARS }}=2 v_{\text {pump }}-v_{\text {Stokes }}
$$

発生する CARS 光强度 $I_{\mathrm{CARS}}$ は分子密度 $N$, ボンブ光强度 $I_{\text {pump }}$ およびストークス光強度 $I_{\text {Stokes }}$ を用いて以下の式で表 される。

$$
I_{\text {CARS }} \propto N^{2} I_{\text {punp }}^{2} I_{\text {Stokes }}
$$

式(2)より, CARS 光強度は分子密度 $N$ の 2 乗に比例するた め, CARS 光強度から誥料分子の濃度を計測することが可 能となる。

\section{3. 実験装置および条件}

本研究で構築した CARS 顕微鏡システムをFig. 1 に示す. Ti:Sapphire レーザからの光をストークス光，その出力の一 部を光パラメトリック発振器(OPO)により波長変換した光

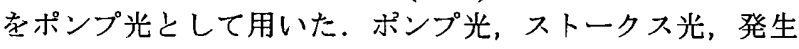

した CARS 光の波長及びラマンシフトを Table 1 に示す. 2 本の励起光はダイクロイックミラーにより光軸を重ね合わ せ, 微動スラーージにより光路長の調整を行い, 励起光のパ ルス在時間的に重初合わせた：その後，対物レンズにより 集光させ，流路内で CARS 光を発生させた. CARS 光は対 物レンズ，フィルタ，ダイクロイックミラーを介して EM-CCDカメラにより撮像した。なお，本装置による CARS 光発生領域は $2.5 \times 2.5 \times 44.5 \mu \mathrm{m}^{3}$ であった。

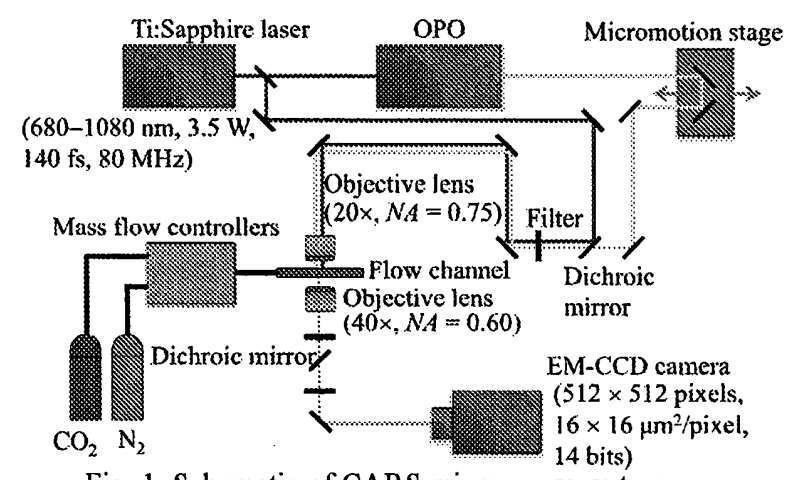

Fig. 1. Schematic of CARS microscopy system.

Table 1. Wavelength of each beam

\begin{tabular}{|l|c|c|c|c|}
\hline & $\begin{array}{c}\text { Pump } \\
\text { beam }\end{array}$ & $\begin{array}{c}\text { Stokes } \\
\text { beam }\end{array}$ & CARS & $\begin{array}{c}\text { Raman } \\
\text { shift }\end{array}$ \\
\hline $\mathrm{CO}_{2}$ & $720 \mathrm{~nm}$ & $800 \mathrm{~nm}$ & $655 \mathrm{~nm}$ & $1388 \mathrm{~cm}^{-1}$ \\
\hline $\mathrm{N}_{2}$ & $727 \mathrm{~nm}$ & $876 \mathrm{~nm}$ & $622 \mathrm{~nm}$ & $2331 \mathrm{~cm}^{-1}$ \\
\hline
\end{tabular}

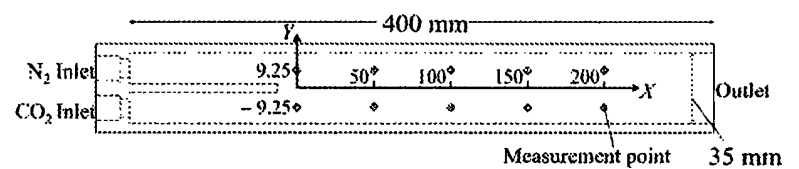

Fig. 2. Top view of the flow channel.

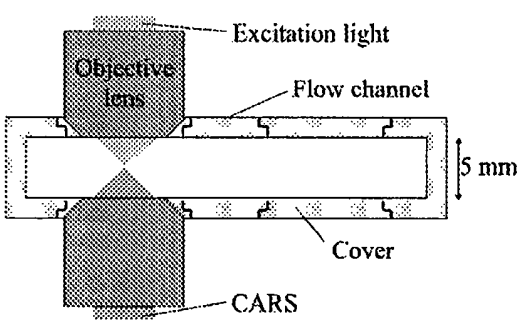

Fig. 3. Cross-sectional view of the flow channel. 
本研究で使用した流路の上面図を Fig. 2 に示す，流路に は $\mathrm{CO}_{2}$ 流入側 $(Y=-9.25 \mathrm{~mm}), \mathrm{N}_{2}$ 流入側 $(Y=9.25 \mathrm{~mm})$ にそ れぞれX方向に $50 \mathrm{~mm}$ 間隔で 5 箇所の計測点設けた。流 路の横断面図を Fig. 3 に示寸. 冬計測点にあけられた穴の 上下に対物レンズをはめ込み，各気体からの CARS 光强度 の計測を行い, CARS 光発生領域内での $\mathrm{CO}_{2}$ 及び $\mathrm{N}_{2}$ 濃度を 計測した. 計測におけ方露光時間驻 $1.57 \mathrm{~s}$, 撮像枚数结 5 枚とした.

\section{4. 結果}

\section{1 較正曲線の取得}

本研究では $\mathrm{CO}_{2}$ 及び $\mathrm{N}_{2}$ の濃度訃測に先駆けて, $\mathrm{CO}_{2}$. $\mathrm{N}_{2}$ 混合比とCARS 光強度の関倸を示す較正曲線を取得した。 較正曲線はあらかじめ流量計に上り混合比を調整した $\mathrm{CO}_{2} \cdot \mathrm{N}_{2}$ 混合気体を流路に注入し，各混合比における CARS 光強度を計測することで取得した。計測点を変更すること による較正曲楾一の影響を検証するため, $Y=9.25 \mathrm{~mm}$ 上の 5 つの計測点においてそれぞれ $\mathrm{CO}_{2}$ の較正曲線を取得し た. 5 枚の画像を時間平均し CARS 光発生領域内の輝度值を 積算した結果を Fig. 4 に示す.この結果より, 計測点の変 更により較正曲線が異なることが確認できた. $\mathrm{N}_{2}$ こついて も同様に $Y=9.25 \mathrm{~mm}$ 上の 5 点における較正曲線を取得し， 得りれた結果を Fig. 5 に示す.よって本砳究では各計測点 に执いて較正曲称取得した後に，各気体からのCARS 光 強度を計測し濃度計測を行った。

\section{2 濃度計測}

$\mathrm{CO}_{2}$ 及び $\mathrm{N}_{2}$ をそれぞれの流入山から流量 $10 \mathrm{~L} / \mathrm{min}$ で注 入し, 混合場形成した. 各気体からの CARS 光強度をも とに算出された $\mathrm{CO}_{2}$ 及び $\mathrm{N}_{2}$ 濃度分布の結果をそれぞれ Fig. 6, Fig. 7 に示す. エラーバーは $5 つ 0$ 計測デー乡の標準偏 差を示す.これにより，流路の下流方向に進むに従い， $\mathrm{CO}_{2}$ と $\mathrm{N}_{2}$ の混合が進行していることが確認でき, CARS 光の発 生領域における $\mathrm{CO}_{2}$ 及び $\mathrm{N}_{2}$ 濃度計測を実現した。 また, $\mathrm{CO}_{2}$ 濃度の計測結果の標準偏差は最大で $3.90 \%, \mathrm{~N}_{2}$ 濃度の 計測結果の標準偏差は最大で $5.58 \%$ \%あった. CARS 光強 度は式(2)よりボンブ光強度の 2 乗及びストークス光強度に 比例し，励起光強度の摇らぎに大きく影響される.このた め, レーザ光強度の摇らぎが計測結果のばらつきの要因と なったと考えられる.今後は, CARS 光の参照值を取得し 各気体からの CARS 光強度を除寸ることにより,レーザ光 の摇らぎによる影響を低減する必要がある。

\section{5. 結言}

微小流路内に扔ける気体の挙動解明に向けて, CARS 顕 微鏡を用いた $\mathrm{CO}_{2} \cdot \mathrm{N}_{2}$ 混合気流の濃度分布非侵襲計測を行 った. 各気体加らの CARS 光を用い, $\mathrm{CO}_{2} \cdot \mathrm{N}_{2}$ 混合気流内 の 10 箇所において $\mathrm{CO}_{2}$ 及び $\mathrm{N}_{2}$ 濃度を計測した.これによ り, 流路の下流方向に進むに従って $\mathrm{CO}_{2}$ と $\mathrm{N}_{2}$ が混合して いる様子が確認でき，マイクロスクールのCARS 光発生領 域での気体濃度計測を実現した。 以上により，マイクロス ケールにおける気体の非侵襲計測に対寸る木手法の有効性 が示された。

\section{謝辞}

本研究は（独）日本学術振興会科学研究費補助金・基盤 研究 (A) (No. 23246037)，挑戦的萌芽研究 (No. 24656144) および特別研究員奖励費（No. 24-7201）の助成を受けた。 ここに謝意を表す。

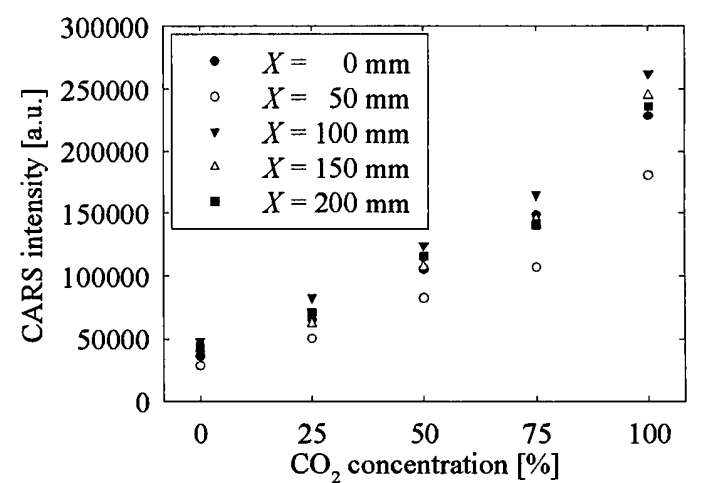

Fig. 4. Relationship between $\mathrm{CO}_{2}$ concentration and CARS intencity at each $X$ position.

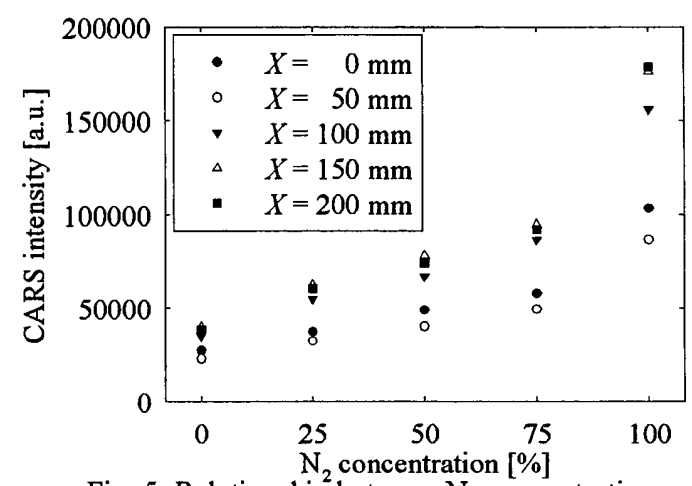

Fig. 5. Relationship between $\mathrm{N}_{2}$ concentration and CARS intencity at each $X$ position.

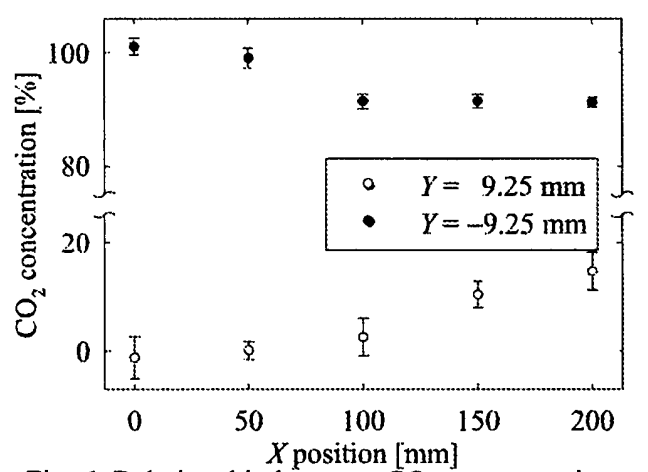

Fig. 6. Relationship between $\mathrm{CO}_{2}$ concentration and $X$ position.

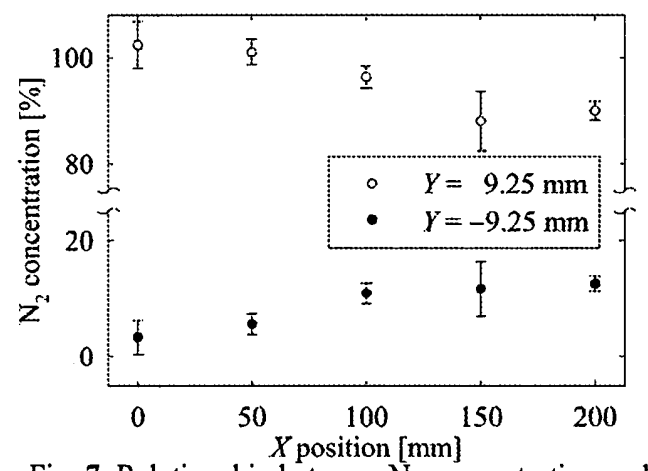

Fig. 7. Relationship between $\mathrm{N}_{2}$ concentration and $X$ position.

\section{参考文献}

(1) Ohira, S. et al., Lab Chip, 5 (2005), 1374-1379.

(2) Ichiyanagi, M. et al., Int. J. Heat Mass Tran., 55 (2012), 2872-2878.

(3) Roy, S. et al., Combust. Flame, 138 (2004), 273-284. 